DOI https://doi.org/10.18551/rjoas.2018-08.06

\title{
THE EFFECT OF PRODUCT INNOVATION AND INNOVATION PROCESS ON PERFORMANCE OF MANUFACTURING COMPANIES LISTED IN INDONESIA STOCK EXCHANGE DURING 2014-2016
}

\author{
Nurhayati Widia Rizqu \\ Department of Accounting, Faculty of Economics and Business, \\ University of Airlangga, Indonesia \\ E-mail: widia.rizqu@gmail.com
}

\begin{abstract}
The purpose of this study is to examine the effect of product innovation and process innovation on company performance in manufacturing companies listed on Indonesia Stock Exchange (IDX) period 2014-2016. Research variables: Dependent variable (firm performance) and independent variable (product innovation and process innovation). Measurement: company performance measured by ROA ratio, product innovation measured by PRODUCT ratio, and process innovation measured by PROCESS ratio. Sources of this research data is secondary data, in the form of financial statements of manufacturing companies listed in IDX during the period 2014-2016. Data analysis technique used is regression analysis through SPSS. The results of this study indicate that product innovation has a positive effect on company performance, while process innovation has no positive effect on company performance. The contribution of this research is expected to give contribution to company about policy which can help improve company performance in relation to product innovation and innovation process done by company and expected also can give contribution for investor to consider innovation strategy done by company in effort to increase profit from investment which they invested in a company.
\end{abstract}

\section{KEY WORDS}

Product, innovation, process, company, performance.

Indonesia as part of the Southeast Asian region has challenges facing a free market within the Southeast Asian region known as the ASEAN Economic Community (MEA). The implementation of the MEA provides a challenge for companies in Indonesia to seize market opportunities in an increasingly competitive business environment. Companies are required to meet the needs of corporate stakeholders in maintaining a company.

A variety of strategic policies run the company to survive and able to maintain the continuity of its business. Innovation strategy is one of strategy policy that many companies use to face business competition. The innovation strategy further directs the company to prioritize their innovation improvement rather than defeating it by destroying its competitors. The company strives to create product innovation in order to produce competitive advantage compared to its competitors' products.

Creativity development of a product can be done based on market demand pressure or the development of production technology. Products that do not develop will have an impact on boredom on consumers, so that consumers can find new product alternatives in accordance with their expectations. It provides an opportunity for consumers to switch to other brands. The innovation strategy is a strategy directed to the process of discovery, development, and implementation of new ideas related to the development of processes, technologies and products (Slater and Olson, 2001).Continuous innovation can provide an alternative for companies in setting priorities for competitive strategy, not only prioritizing cost leadership, but also on quality leads, delivery, and responsiveness(Means and Faulkner, 2000).

Research conducted by Atalay et al. (2013) provide empirical evidence that product innovation provides a poetic effect for company performance. The development of new products from the use of existing technology provides an opportunity for companies to attract 
as many markets at the price level they specify. This gives a positive impact on the increase in profits generated by the company. Atalayet al. (2013) conducted at 113 automotive companies in Konya.

Research conducted by Atalay et al. (2013) contrary to research conducted by Karlsson and Tavassoli (2015). Karlsson and Tavassoli (2015) provide empirical evidence that companies that innovate processes do not have an impact on company performance. This is because the number of product innovations that occur requires the development of knowledge and technology that require a large cost in running it. Costs greatly impact on the decline in company performance, due to the large cost incurred for new technologies.

Due to inconsistencies in previous research, it is important to reexamine the effect of product innovation and process innovation on company performance. This research is expected to provide information to the company about the policies that can help improve the company's performance in solving it with product innovation and process innovation conducted by the company. This research is also expected to contribute to the investor to consider the innovation strategy undertaken by the company in an effort to increase the profits from the investment that they planted in a company.

\section{THEORY AND HYPOTHESES DEVELOPMENT}

Stakeholders Theory. A stakeholder approach emerged in the mid-1980s. The background of a stakeholder approach is the desire to build a framework that is responsive to the problems facing managers at that time of environmental change (Freeman and McVea 2001). The goal of stakeholder management is to devise methods for managing the various groups and relationships generated in a strategic way (Freeman and McVea, 2001). Stakeholders are individuals or groups of individuals who can influence or be influenced by the achievement of company goals (Freeman, 2010: 25).

Company performance. Performance is an important thing that must be achieved by every company anywhere, because the performance is a reflection of the company's ability to manage and allocate resources. In addition, the ultimate goal of performance appraisal is to motivate employees to achieve organizational goals and in complying with predetermined standards of behavior, in order to produce the expected actions and results. The performance of the company is the achievement of the business as the objective of the company is established that is getting the maximum profit to be able to sustain growth and development. There are several criteria in assessing a company's performance delivered in various literatures. These criteria include operational and financial (Suta, 2007: 12).

Innovation. Innovation can occur in companies both from the private sector or the public sector does not even close the possibility that innovation occurs within government companies, non-profit companies, and also government agencies. Law No.18 of 2002 on national systems of research, development, and application of science and technology defines innovation as a research, development and / or engineering activity aimed at developing practical application of new values and scientific contexts, or new ways to apply existing science and technology into products or production processes. Schumpeter (1939) in (Küçükoğlu \& Pınar, 2015) argues that innovation is:

"Innovation is the implementation of technical or organizational novelty, not just its invention or development".

Product Innovation. In the OECD Oslo Manual (2005), a product innovation is defined as the introduction of new goods or services or significant product improvements. This includes significant improvements in technical specifications, components and materials, software combinations, or other functional characteristics. Product innovation can take advantage of new knowledge or technology, or it can be based on a new usage or combination of existing knowledge or technology.

Process Innovation. Innovation process is a new implementation, a significant increase in production produced or an increase in delivery methods. The parts included in process innovation are significant changes in production techniques, equipment and / or software used. Process innovation can be aimed at reducing unit cost of production or delivery, to 
improve quality, or to increase production significantly or produce new products (OECD Oslo Manual, 2005).

Previous Research. Research conducted by Faria and Lima (2009) on the influence of innovation type on the performance of companies conducted on manufacturing and service companies in Portugal. The research was conducted during 1998 to 2000. The results of Faria and Lima (2009) provide empirical evidence that product, process and organizational innovation has positive and significant impact on company performance.

Research conducted by Atalay et al. (2013) on the effect of innovation on company performance conducted on 113 automotive supplier companies operating in Konya. The study was conducted during the period of March to December 2011. The study was conducted by conducting direct interviews with top managers of automotive supplier companies. The results of Atalay et al. (2013) provide empirical evidence that product innovation and process innovation have a positive and significant impact on company performance. Atalay et al. (2013) also gives results that innovation marketing and organizational innovation does not provide a significant effect on the performance of the company.

Research conducted by Karlsson and Tavassoli (2015) on the influence of innovation strategies on corporate performance conducted on the innovation community in Sweden. The study was conducted during 2002 to 2012. The results of Karlsson and Tavassoli (2015) provide empirical evidence that product innovation has a positive and significant effect on company performance. Karlsson and Tavassoli (2015) research also gave results that process innovation and marketing innovation did not have a significant effect on company performance. Innovation should be done by using more than one form of innovation model in order to provide better results for the improvement of company performance in the present and future.

The Influence of Product Innovation on Financial Performance. To face competition and to answer market challenges, every company is required to innovate products. Product innovation is introducing new products that are a new combination of characteristics that align with the preferences of potential customers or alter the characteristics of current products in a way that increases the willingness of potential customers to pay for the overall characteristics created. Product innovation is a difficult and demanding process of technological advancement, changing customer needs, shortening product life cycles, and increasing global competition. Fagerberg et al.(2004) emphasized that the introduction of new products generally has clarity, and has a positive effect on revenue growth because of the cutting of production costs.

Research conducted by Faria and Lima (2009), Atalay et al. (2013), Kalay and Lynn (2014), Karlsson and Tavassoli (2015), Rosli and Sidek (2015), and Bartolini and Baussola (2015) provide empirical evidence that product innovation has a positive and significant impact on company performance. The greater the innovation of products produced by a company, the greater the performance of the company. Based on the description above, the hypothesis built in this study are:

$\mathrm{H}_{1}$ : Product innovation has a positive effect on company performance.

Influence of Process Innovation on Financial Performance. Innovation process is a new implementation, a significant increase in production produced or an increase in delivery methods. The parts included in process innovation are significant changes in production techniques, equipment and / or software used. Process innovation can be aimed at reducing unit cost of production or delivery, to improve quality, or to increase production significantly or produce new products (OECD Oslo Manual, 2005).

Research conducted by Peters (2015) provides empirical evidence that process innovation has a positive and significant impact on company performance. The greater the innovation process produced by a company, the greater the performance of the company. Based on the description above, the hypothesis built in this study are:

$\mathrm{H}_{2}$ : Process innovation has a positive effect on company performance. 


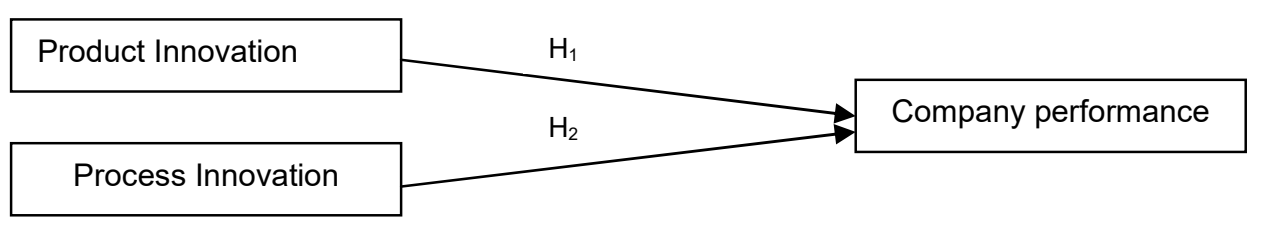

Figure 1 - Conceptual Framework

\section{METHODS OF RESEARCH}

Types of Research. This type of research is quantitative with an associative research approach. Assosiative research aims to determine the correlational relationship and causal relationships between variables (Sulistyanto et al., 2006: 14).

Identify Variables:

- Dependent variable in this research is company performance;

- Independent variables used in this study are product innovation and process innovation.

Operational Definition of Variables:

Company Performance. Company performance is a view of the company's financial condition over the period in the future. Company performance measurements are useful to provide information about the appearance of the company's condition for a certain time in the future. In this study, the company's performance is measured by the company's financial condition in the future. According to Hongren (2007: 372), the measurement of financial performance has a goal to measure business performance and management compared to company goals. In this research future financial performance is measured by using return on asset ratio (ROA) for 2 (two) years ahead. Return on asset ratio is one form of profitability ratios that can give a picture of how the company's ability to generate profits from operational activities undertaken. The return on asset ratio is calculated using the formula:

$$
R O A=\frac{\text { Net Profit }}{\text { Total Assets }}
$$

Product Innovation. Product innovation involves strong interaction within the company and further between the company and its customers and suppliers (Akova et al, 1998). The greater the company's innovation in improving existing products, and the greater the company's ability to produce new products, will have an impact on the company's ability to face competition. Product innovation in this research uses measurement of PRODUCT ratio (Simeth and Cincera, 2013). PRODUCT Ratio is measured using the formula:

$$
P R O D U C T=\frac{\text { Research and Development Expense }}{\text { Total Assets }}
$$

Process Innovation. Process innovation is a new implementation or a significant increase in production. Process innovation is made by making significant changes in production techniques, equipment and / or software used. Process innovation is intended to reduce unit cost of production or delivery, to improve quality, or to increase production significantly or produce new products (OECD Oslo Manual, 2005). In this research, process innovation diokurrasio PROCESS calculated by using the formula:

$$
\text { PROCESS }=\frac{\text { Expense }(I T+\text { Machinery }+ \text { Equipment })}{\text { Total Assets }}
$$




\section{RESULTS AND DISCUSSION}

Table 1 - Descriptive Statistics Test Results

\begin{tabular}{llllll}
\hline & $\mathrm{N}$ & Minimum & Maximum & Mean & Std. Deviation \\
Return on Assets (ROA) & 183 & 0.0011 & 0.8557 & 0.137204 & 0.1207498 \\
PRODUCT & 183 & 0.0000 & 0.5592 & 0.144158 & 0.1143420 \\
PROCESS & 183 & 0.0028 & 0.8007 & 0.187162 & 0.159398 \\
Valid N (listwise) & 183 & & & & \\
\hline
\end{tabular}

Source: Data Processed, 2017.

Based on the results of statistical descriptive test can be seen in Table 1, note that the average value of Return on Assets (ROA) of 0.137204 . The highest value of Return on Assets (ROA) of 0.8557 is owned by PT Multi Bintang Indonesia Tbk in 2014. The lowest value of Return on Assets (ROA) of 0.0011 is owned by PT Multistrada Arah Sarana Tbk in 2014.

The average product value is 0.144158 . The highest product value of 0,5592 is owned by PT Hanjaya Mandala Sampoerna Tbk in 2016. The product's lowest value of 0.0000 is owned by PT Siearad Produce Tbk in 2015.

The average value of Process is 0.187162 . The highest value of the Process of 0.8007 is owned by PT Kabelindo Murni Tbk in 2014. The Process's lowest value of 0.0028 is owned by PT Asiaplast Industries Tbk in 2014.

Table 2 - Normality Test Results

\begin{tabular}{lll}
\hline & & Unstandardized Residual \\
\hline $\mathrm{N}$ & & 183 \\
Normal Parameters & Mean & 0.00000000 \\
& Std. Deviation & 0.11626640 \\
Most Extreme Differences & Absolute & 0.153 \\
& Positive & 0.153 \\
& Negative & -0.119 \\
Kolmogorov-Smirnov Z & & 2,068 \\
Asymp. Sig. & & 0,000 \\
\hline
\end{tabular}

Source: Data Processed, 2017.

Based on the results of normality test can be seen in Table 2, note that the value of Sign. This 0.000 is less than $0.05(0.000<0.05)$. This shows that the data used in this study is not abnormal distribution (homogeny data). The significance value of the normality test based on Ghozali (2013), if the value of Sign>> 0,05 means the data is normally distributed, whereas if Sign value $<0,05$ means the data is not normally distributed.

Table 3 - Autocorrelation Test Results

\begin{tabular}{llllll}
\hline Model & $\mathrm{R}$ & $\mathrm{R}$ Square & Adjusted R Square & Std. Error of the Estimate & Durbin-Watson \\
\hline 1 & 0.270 & 0.073 & 0.063 & 0.1169105 & 1,696 \\
\hline
\end{tabular}

Source: Data Processed, 2017.

Table 4 - Multicollinearity Test Results

\begin{tabular}{|c|c|c|c|c|c|c|c|}
\hline \multirow{5}{*}{$\begin{array}{ll}\text { Model } \\
1 & \text { (Constant) } \\
& \text { PRODUCT } \\
& \text { PROCESS }\end{array}$} & \multicolumn{2}{|c|}{ Unstandardized Coefficients } & \multirow{2}{*}{$\begin{array}{l}\text { Standardized Coefficients } \\
\text { Beta }\end{array}$} & \multirow[b]{2}{*}{$\mathrm{t}$} & \multirow{3}{*}{$\begin{array}{l}\text { Sig. } \\
0,000\end{array}$} & \multicolumn{2}{|c|}{ Collinearity Statistics } \\
\hline & B & Std.Error & & & & Tolerance & VIF \\
\hline & 0.098 & 0.016 & & 6,140 & & & \\
\hline & 0.289 & 0.078 & 0.274 & 3,715 & 0,000 & 0.949 & 1.054 \\
\hline & -0.015 & 0.056 & $-0,020$ & $-0,269$ & 0.788 & 0.949 & 1.054 \\
\hline
\end{tabular}

Source: Data Processed, 2017

Based on the autocorrelation test results can be seen in Table 3 it is known that the Durbin-Watson value of 1.696 , this value is smaller than $2(1.696<2)$. This indicates that the data used in this study is free of autocorrelation symptoms or there is no correlation between 
intrusion errors in the period 2016 with intrusion errors in the period 2015 and 2014. The significance value of autocorrelation tests based on Ikhsan et. al (2014) , if the DurbinWatson value between -2 to +2 means there is no autocorrelation.

Based on the results of multicollinearity test can be seen in Table 4 it is known that the product tolerance value of 0.949 , this value is greater than $0.1(0.949>1)$ and VIF Product value of 1.054 , this value is smaller than $10(1.054<10)$. The tolerance value is 0.949 , this value is greater than $0.1(0.949>1)$ and the VIF Process value is 1.054 , this value is less than $10(1,054<10)$. Overall, the tolerance value of Product and Process is greater than 0.1 , whereas the VIF Product and Process value is smaller than 10. This indicates that, the data used in this study is free from the symptoms of multicollinearity. The value of significance of multicollinearity test based on Ghozali (2013), if tolerance value $>0,1$ and VIF value $<10$, then the data in research is free from multicollinearity symptoms.

Table 5 - Heteroscedasticity Test Results

\begin{tabular}{|c|c|c|c|c|c|}
\hline \multirow[b]{2}{*}{ Model } & \multicolumn{2}{|c|}{ Unstandardized Coefficients } & \multirow{2}{*}{$\begin{array}{l}\text { Standardized Coefficients } \\
\text { Beta }\end{array}$} & \multirow{2}{*}{$t$} & \multirow{2}{*}{ Sig. } \\
\hline & B & Std. Error & & & \\
\hline $1 \quad$ (Constant) & 0.049 & 0.011 & & 4.355 & 0,000 \\
\hline PRODUCT & 0.214 & 0.055 & 0.285 & 3,879 & 0,000 \\
\hline PROCESS & -0.011 & 0.040 & $-0,021$ & $-0,290$ & 0.772 \\
\hline
\end{tabular}

Source: Data Processed, 2017.

Based on the results of heteroscedasticity test can be seen in Table 5 note that the value of Sign. Product of 0.000 , this value is smaller than $0.05(0.000<0.05)$. Sign Value. Process of 0.772 , this value is greater than $0.05(0.772>0.05)$. Overall, the value of Sign. Process is greater than 0.05 , while Product value is less than 0.05 . This shows that the data used in this study is free from symptoms of heteroscedasticity. The significance value of heteroscedasticity test based on Ghozali (2013), if the value of Sign. $>0.05$, then the data in the study free of symptoms of heteroscedasticity.

Table 6 - Coefficient Determination Test Results

\begin{tabular}{lllll}
\hline Model & $\mathrm{R}$ & $\mathrm{R}$ Square & Adjusted R Square & Std. Error of the Estimate \\
\hline 1 & 0.270 & 0.073 & 0.063 & 0.1169105 \\
\hline
\end{tabular}

Source: Data Processed, 2017.

Based on the test results coefficient of determination $\left(R^{2}\right)$ can be seen in Table 6 note that $R^{2}$ of 0.073 . This shows that $7.3 \%$ variation variables of the dependent variable is company performance can be explained by two (2) independent variable that is innovation product and innovation process. While the remaining $92.7 \%$ is explained by other factors outside the model of this study.

Table 7 - Test Result F

\begin{tabular}{|c|c|c|c|c|c|c|}
\hline \multicolumn{2}{|c|}{ Model } & Sum of Squares & $\mathrm{df}$ & Mean Square & $\mathrm{F}$ & Sig. \\
\hline \multirow[t]{3}{*}{1} & Regression & 0.193 & 2 & 0.097 & 7,075 & 0.001 \\
\hline & Residual & 2,460 & 180 & 0.014 & & \\
\hline & Total & 2,654 & 182 & & & \\
\hline
\end{tabular}

Source: Data Processed, 2017.

Table 8 - Test Result t

\begin{tabular}{lllrrrr}
\hline & Unstandardized Coefficients & \multicolumn{2}{c}{ Standardized Coefficients } & T & Sig. \\
Model & B & Std. Error & Beta & & 6,140 & 0,000 \\
1 & (Constant) & 0.098 & 0.016 & 0.274 & 3,715 & 0,000 \\
& PRODUCT & 0.289 & 0.078 & $-0,020$ & $-0,269$ & 0.788 \\
\hline
\end{tabular}

Source: Data Processed, 2017. 
Based on $\mathrm{F}$ test results can be seen in Table 7 note that the value of $\mathrm{F}$ equal to 7.075 with a probability of 0.001 . The probability value is less than $0.05(0.001<0.05)$. This suggests that, the regression model can be used to detect the value of firm performance. Thus, other variables such as innovation product and innovation process together have an influence on company performance.

Based on t test results can be seen in Table 8 note that the value of Sign. Product of 0.000 , this value is smaller than $0.05(0.000<0.05)$. This indicates that $H_{1}$ is accepted, meaning that product innovation positive $f$ influence on company performance. The development of new products from the use of existing technology provides an opportunity for companies to attract as many markets at the price level they specify. The greater the innovation of products produced by a company, the greater the company's performance. This gives a positive impact on the increase in profits generated by the company. The results of this study are in line with the results of research conducted by Faria and Lima (2009), Atalay et al. (2013), Kalay and Lynn (2014), Karlsson and Tavassoli (2015), Rosli and Sidek (2015), and Bartolini and Baussola (2015) provide empirical evidence that product innovation has a positive and significant impact on company performance.

Sign Value. Process of 0.788 , this value is greater than $0.05(0.788>0.05)$. This indicates that $\mathrm{H}_{2}$ is rejected, meaning that innovation process has no positive effect on company performance. The results of this study are in line with the results of research conducted by Karlsson and Tavassoli (2015) provide empirical evidence that companies that innovate the process do not have an impact on company performance. This is because the number of product innovations that occur requires the development of knowledge and technology that require a large cost in running it. Costs greatly impact on the decline in company performance, due to the large cost incurred for new technologies.

\section{CONCLUSION}

This research was conducted to test the effect of product innovation and process innovation on company performance on manufacturing companies listed on IDX period 20142016. The test results show that product innovation positive $f$ influence on company performance. This suggests that the development of new products from the use of existing technology provides an opportunity for companies to attract as many markets at the price level they specify. The greater the innovation of products produced by a company, the greater the company's performance. This gives a positive impact on the increase in profits generated by the company. Meanwhile, the results of testing on process innovation do not affect positive $f$ on company performance. This is because the number of product innovations that occur requires the development of knowledge and technology that require a large cost in running it. Costs greatly impact on the decline in company performance, due to the large cost incurred for new technologies.

The contribution of this research is expected to be used as input or additional empirical evidence about the effect of product innovation and process innovation on company performance. This research is expected to provide benefits for the contribution of science, especially related to management decisions in conducting innovation policies that affect the performance of the company. For leaders and policy makers within the company, this research is expected to be a reference in determining policies related to innovation to be taken in order to improve company performance. This research is expected to provide useful information for readers, especially investors in making decisions to buy or sell shares in connection with the existence of innovation policies made by the company.

For future research, it is expected to examine each component of product innovation and process innovation more specifically in order to know more about each contribution a to company performance. The population of the research sample should not be limited to manufacturing companies but can be done in other sectors such as construction and mining sectors in order to know which sector of the company has been managing product innovation and process innovation well that can show significant influence to company performance. Future research should always use the closest period of time from the time the research is 
conducted in order to find out the latest trends in product innovation management and process innovation and its effect on company performance from year to year more accurately.

\section{REFERENCES}

1. Arikan, S., Akova, U., Hayran, M., Özdemir, O., Erman, M., Gür, D., \&Ünal, S. (1998). Correlation of in vitro fluconazole susceptibility with clinical outcome for severely ill patients with oropharyngeal candidiasis. Clinical infectious diseases, 26(4), 903-908.

2. Atasu, A., Özdemir, Ö.,\& Van Wassenhove, L. N. (2013). Stakeholder perspectives on E-waste take-back legislation. Production and Operations Management, 22(2), 382-396.

3. Fagerberg, J. (2004). Innovation: a guide to the literature. Georgia Institute of Technology.

4. Fernandes, V. B. L., Caldeira, A. P., de Faria, A. A., \&Neto, J. F. R. (2009). Internações sensíveis na atenção primária como indicador de avaliação da Estratégia Saúde da Família. Revista de Saúde Pública, 43(6), 928-936.

5. Freeman, R. E., \&McVea, J. (2001). A stakeholder approach to strategic management.

6. Ghozali, Imam. (2013). Analisis Multivariate Program IBM SPSS 21. Semarang: Badan Penerbit Universitas Diponegoro.

7. Horngren, C. T., Sundem, G. L., \& Stratton, W. O. (2007). Contabilidad administrativa. Pearson Educación.

8. Ikhsan, Arfan, Muhyarsyah, Hasrudy Tanjung, dan Ayu Oktaviani. (2014). Metodologi Penelitian Bisnis Untuk Akuntansi dan Manajemen. Bandung: Citapustaka Media.

9. Karlsson, C., \&Tavassoli, S. (2015). Innovation Strategies and Firm Performance. Centre of Excellence for Science and Innovation Studies Working Paper Series, 401.

10. Küçükoğlu, M. T., \& Pınar, R. İ. (2015). Positive influences of green innovation on company performance. Procedia-Social and Behavioral Sciences, 195, 1232-1237.

11. Le Quéré, C., Moriarty, R., Andrew, R. M., Peters, G. P., Ciais, P., Friedlingstein, P., Boden, T. A. (2015). Global carbon budget 2014. Earth System Science Data, 7(1), 4785.

12. Leybourne, S., Lynn, G., \&ThanningVendelø, M. (2014). Forms, metaphors, and themes: an introduction to the special issue on organizational improvisation. Creativity and Innovation Management, 23(4), 353-358.

13. Means, G. E., \& Faulkner, M. (2000). Strategic innovation in the new economy. journal of Business Strategy, 21(3), 25-29.

14. Mohamad, M. R., Sidek, S., Ghee, W. Y., Abdullah, A. R., Ismail, N. A., \& Mustapha, N. (2015). Financial access for starting a business: Evidence of internal and external financial sources, and performance of Malaysian SMEs. Journal of Entrepreneurship and Business, 3(1), 1-16.

15. Oecd, E. (2005). Oslo Manual. Guidelines for collecting and interpreting innovation data,.

16. Oyarzo, M., Romani, G., Atienza, M., \&Lufin, M. (2015). Spatio-temporal persistence of municipal rates of business start-ups in Chile (No. 63). Universidad Catolica del Norte, Chile, Department of Economics.

17. Schumpeter, J. A. (1939). Business cycles (Vol. 1, pp. 161-74). New York: McGraw-Hill.

18. Simeth, M., \&Cincera, M. (2015). Corporate science, innovation, and firm value. Management Science, 62(7), 1970-1981.

19. Slater, S. F., \& Olson, E. M. (2001). Marketing's contribution to the implementation of business strategy: an empirical analysis. Strategic Management Journal, 22(11), 10551067.

20. Suta. (2007). Pengaruh Kinerja Keuangan Terhadap Harga Saham Pada Perusahaan Sektor Industri Barang Konsumsi yang terdaftar di Bursa Efek Indonesia Periode 20072011 (Doctoral dissertation, Unversitas Negeri Gorontalo). 